\title{
Carcass and retail meat cuts quality properties of broiler chicken meat based on the slaughter age
}

\author{
Sin-Young Park, Dong-Seob Byeon, Gye-Woong Kim and Hack-Youn Kim* \\ Department of Animal Resources Science, Kongju National University, Chungnam 32439, Korea
}

Received: Sep 1, 2020

Revised: Oct 14, 2020

Accepted: Oct 20, 2020

${ }^{*}$ Corresponding author Hack-Youn Kim

Department of Animal Resources Science, Kongju National University, Chungnam 32439, Korea.

Tel: +82-41-330-1041

E-mail: kimhy@kongju.ac.kr

Copyright (๑) 2021 Korean Society of Animal Sciences and Technology. This is an Open Access article distributed under the terms of the Creative Commons Attribution Non-Commercial License (http:// creativecommons.org/licenses/by$\mathrm{nc} / 4.0 /$ ) which permits unrestricted non-commercial use, distribution, and reproduction in any medium, provided the original work is properly cited.

ORCID

Sin-Young Park

https://orcid.org/0000-0001-7900-5987

Dong-Seob Byeon

https://orcid.org/0000-0002-7099-7016

Gye-Woong Kim

https://orcid.org/0000-0001-7325-9898

Hack-Youn Kim

https://orcid.org/0000-0001-5303-4595

Competing interests

No potential conflict of interest relevant to this article was reported.

Funding sources

This work was carried out with the support of "Cooperative Research Program for Agriculture Science \& Technology Development (Project No. PJ01528103)" Rural Development Administration, Korea.

Acknowledgements

This work was carried out with the support of "Cooperative Research

\section{Abstract}

This study aimed to determine the carcass and meat quality of broiler chickens based on the slaughter age $(28,30,32$, and 34 days). The carcass characteristics included live and carcass weights, carcass rate, dressing rate, and retail cut weight. The meat quality properties were determined through proximate composition, $\mathrm{pH}$, color, water holding capacity (WHC), cooking yield, and shear-force. The broiler chicken live, carcass, breast, thigh, and wing weights significantly increased with the slaughter age $(p<0.05)$; the tenderloin weight also exhibited a similarly increasing trend. However, the carcass rate of the day 28 sample was significantly lower than the other samples $(p<0.05)$. The protein and ash contents of the breast exhibited an increasing trend with increasing slaughter age. The protein content of the thigh of the day 28 sample was significantly lower than that of the other samples $(p<0.05)$, while the ash contents of the day 28 and 30 samples were significantly lower. The redness of the breast showed an increasing trend, and the $\mathrm{pH}$ and lightness of the thigh exhibited a decreasing trend with slaughter age. The WHC and cooking yields of the day 30 and 32 breast and thigh samples were significantly higher than those of the day 28 and 34 samples ( $p<$ $0.05)$. The breast and thigh shear-force of the day 30-34 samples were significantly higher than those of the day 28 sample $(p<0.05)$. The present study showed that even with a twoday difference in slaughter age, the broiler chicken meat quality showed a significant difference in several characteristics.

Keywords: Broiler, Meat quality, Production index, Retail cut, Slaughter age

\section{INTRODUCTION}

The Korean poultry industry has demonstrated continuous advancements regarding meat species compared to the past and significantly improved the environmental conditions and productivity indicators for broiler chickens (Gallus gallus domesticus). These advancements have resulted in a decreased feed conversion ratio and increased the daily weight gain, shortening the period necessary to achieve the broiler chicken market weight desired by the farms [1]. The average slaughter age of broilers was 31.8-32.8 days, and their slaughter weight was $1.68-1.74 \mathrm{~kg}$ between January and June 2020 in Korea [2]. Previously, Nasr and Kheiri [3] reported that the carcass weight according to slaughter age was $1.0 \mathrm{~kg}$ and $1.6 \mathrm{~kg}$ at 28 and 35 days, respectively. And it was provided by Chae et al. [4], chickens slaughtered at day 30 weighing at least $1.2 \mathrm{~kg}$ were not adequate to meet the demand for retail cuts 
Program for Agriculture Science \& Technology Development (Project No. PJ01528103)" Rural Development Administration, Korea.

Availability of data and material Upon reasonable request, the datasets of this study can be available from the corresponding author.

Authors' contributions

Conceptualization: Kim GW, Kim HY. Data curation: Kim HY.

Formal analysis: Park SY, Byeon DS

Methodology: Kim GW, Kim HY.

Software: Park SY.

Validation: Kim HY

Investigation: Park SY, Byeon DS.

Writing - original draft: Park SY.

Writing - review \& editing: Park SY, Byeon

DS, Kim GW, Kim HY.

Ethics approval and consent to participate This article does not require IRB/IACUC approval because there are no human and animal participants. only from domestic broilers at the time in Korea. This study demonstrated that periodic analyses of broiler growth capability are necessary as the broiler productivity indicators continuously improve in the poultry industry.

In addition to analyzing the overall characteristics of the carcass itself, it is also necessary to analyze retail cuts, as the consumption of broilers in recent years includes a variety of forms with enhanced convenience, and consumption as convenience food is gradually increasing [5]. The most widely-used broiler cut worldwide is the breast, and its demand has continued to soar due to its high protein and low-fat contents, as well as being a popular substitute for meals while on a diet [6]. Similar to breast meat, thigh meat is also a high-in-demand retail cut since it is used in various processed meat products such as barbeque, nuggets, and karaage [5]. However, the self-sufficiency for retail cuts within Korea is relatively low compared to other countries, leading to heavy reliance on imports with 140,077 tons in 2019 [7]. It is expected that the self-sufficiency of retail cuts will become somewhat more stable than in the past due to the improvement of the broiler productivity indicator in Korea.

The effect of raising periods on the carcass characteristics and physio-chemical properties of retail cuts have been previously analyzed in Korean-produced broilers [4,8]. However, it is necessary to increase broiler retail cut use by periodically analyzing the carcass characteristics and retail cut quality according to the typical market days as broiler productivity indicators continue to improve. Therefore, depending on slaughter age, the broiler carcass characteristics and meat quality of the popular retail cuts, including breast and thigh meat, were analyzed in this study.

\section{MATERIALS AND METHODS}

The individual selection and measurement of changes in carcass to slaughter age We used the Ross broiler (Gallus gallus domesticus) as a model in this study, and the slaughter age was set to $28,30,32$, and 34 days. Twenty individual commercially reared broilers were randomly selected immediately after slaughter from a local poultry slaughterhouse, transported to the Kongju National University Meat \& Meat Products Science Laboratory, and refrigerated $4^{\circ} \mathrm{C}$ for $12 \mathrm{~h}$. Each selected individual was classified and assigned a number from the slaughterhouse, and it was used in the experiments. The live-weight (g) was measured as the weight of an individual completing the fasting process before slaughter at the slaughterhouse. Then, the feathers, head, feet, and giblet were removed, the carcass weight (g) was measured, and the carcass rate (\%) was calculated. The individuals were cut for the breast, leg, wing, and tenderloin, and the weights were immediately measured. In the case of the leg, after the weight was measured, the skin was removed and cut into a drumstick. The separated the breast and thigh meat of twenty individual broilers were vacuum-packed, and refrigerated at $4^{\circ} \mathrm{C}$ to be used in the experiment. The following equations were used to calculate the carcass and dressing rates:

$$
\begin{gathered}
\text { Carcass rate }(\%)=\frac{\text { Carcass weight }(\mathrm{g})}{\text { Live weight }(\mathrm{g})} \times 100 \\
\text { Dressing rate }(\%)=\frac{\text { All retail cuts weight }(\mathrm{g})}{\text { Carcass weight }(\mathrm{g})} \times 100
\end{gathered}
$$

\section{Proximate composition}

The proximate composition was measured following the methods in compliance with the AOAC official method 932.06 [9]. The moisture, crude protein, crude fat, and ash contents were measured 
by oven-drying, Kjedahl, Soxhlet, and dry-ashing methods, respectively.

$\mathrm{pH}$

After slaughter, deboning was completed within $14 \mathrm{~h}$, and the $\mathrm{pH}$ measurement was immediately performed after deboning was completed. For the sample collections of breast and thigh meat, $4 \mathrm{~g}$ of lean meat excluding skin was collected, and the sample was placed in a conical tube along with $16 \mathrm{~mL}$ distilled water. Sample preparation was followed by homogenization using an HMZ20DN homogenizer (Poolim Tech, Seongnam, Korea) at 10,923×g for $1 \mathrm{~min}$. The $\mathrm{pH}$ of the prepared mixture was measured using a Model S220 pH meter (Mettler-Toledo, Schwerzenbach, Switzerland).

Color

The color of the outer surface of the skinless breast and thigh samples was measured using a color reader (CR-10, Minolta, Tokyo, Japan) for CIE L* (lightness), CIE a* (redness), and CIE b* (yellowness). A white standard plate (CIE L*: 97.83; CIE a*: -0.43; CIE b*: 1.98) was used as a reference.

\section{Water holding capacity (WHC)}

The sample WHC was measured using the filter paper-press method [10] with slight modifications. Briefly, each $0.3 \mathrm{~g}$ of uncooked chicken breast and thigh sample was placed onto Whatman No. 2 filter paper (GE Healthcare, IL, USA) and compressed for 3 min using a filter-press device. The WHC was calculated using the following methods by measuring the meat- and exudation area. The following formula was used:

$$
\text { WHC }(\%)=\frac{\text { Meat area }\left(\mathrm{mm}^{2}\right)}{\text { Exudation area }\left(\mathrm{mm}^{2}\right)} \times 100
$$

\section{Cooking loss}

The cooking loss was weighed using uncooked chicken breast and thigh heat processed with a chamber $\left(80^{\circ} \mathrm{C}, 40 \mathrm{~min}\right)$. After cooling at $10^{\circ} \mathrm{C}$ for $1 \mathrm{~h}$, cooked samples were weighed (weight after cooking), and the percentage of cooking loss was calculated according to the following formula:

$$
\text { Cooking loss }(\%)=\frac{\text { Weight before cooking }(\mathrm{g})-\text { Weight after cooking }(\mathrm{g})}{\text { Weight before cooking }(\mathrm{g})} \times 100
$$

\section{Shear force}

The shear force of the breast and thigh samples was assessed by cutting samples into $1 \times 2 \times 1 \mathrm{~cm}^{3}$ blocks, and a minimum 7 samples were prepared. Prepared samples of shear force were analyzed using a V-blade attached to a texture analyzer (test speed, $3.0 \mathrm{~mm} / \mathrm{s}$; head speed, $3.0 \mathrm{~mm} / \mathrm{s}$; distance, 19.0 mm; force, $5.6 \mathrm{~N}$; TA 1, Ametek, FL, USA). The measured values were expressed in Newtons $(\mathrm{N})$.

\section{Statistical analysis}

All analyses were performed using an analysis of variance for all variables (ANOVA) procedure of the SAS software program (SAS version 9.3 for Windows; SAS Institute, Cary, NC, USA), and significant differences $(p<0.05)$ were detected using Duncan's multiple range test. The results are 
presented as the mean and SEM.

\section{RESULTS AND DISCUSSION}

\section{Carcass weight}

Table 1 shows the live weight, carcass weight, and carcass rate on different slaughter days. The live weight and carcass weight increased significantly with increasing slaughter age $(p<0.05)$. The carcass rate did not vary significantly between the 30- and 34-day slaughter age, but it was relatively low at the 28-day age, indicating that the slaughter age should be at least 30 days based on the carcass rate. The carcass rate was reported to be $65 \%$ of the live weight in 1995, according to National Institute of Animal Science (NIAS) [11], which was rather different from the results obtained in this study. However, the carcass rates reported in 2010 and 2015 were $71 \%$ at 30 days of slaughter age $[12,13]$ and were more consistent with the current results. Additionally, the breeding performance investigated in this study was found to be similar to that of other countries given the same raising period [3,14], which suggested that the Korean broiler productivity indicators improved significantly. In the Korean poultry industry, the average live weight of broilers distributed in the first half of 2020 was around $1.7 \mathrm{~kg}$, and the corresponded slaughter age was about 32 days [2]. Similarly, in the case of live weight measurement for the slaughter age of 32 days was $1.7 \mathrm{~kg}$. The daily gain at the average slaughter date in Korea was $52.6 \mathrm{~g}$ and $53.8 \mathrm{~g}$ in 2018 and 2019, respectively [2], nevertheless, in this study, the weight gain for 2 days after 28 days of slaughter age was $138 \mathrm{~g}, 217 \mathrm{~g}$, and $234 \mathrm{~g}$, it was found that the weight gain increased as the slaughter age increased. As such, the average slaughter age is generally set to the day that has the best marketability and productivity in consideration of the daily gain [15]. In this study, as a result of measuring live weight and carcass rate by slaughter age, it was found that the marketability of 30-34 days was better than compared to 28 days of slaughter age.

\section{Weight of retail cuts}

Table 2 shows the dressing rate and weight by the cut (breast, thigh, tenderloin, and wing) for different slaughter ages. The dressing rate was significantly lower in the 28-day group $(p<0.05)$ than in the groups of other slaughter ages, similar to the carcass rate. Generally, individual broilers with a short raising period or lower weight showed a trend of lower dressing rate than the average in the poultry industry since the formation of bones takes place prior to muscle development [16]. Similar to the results published by Devatkal et al. [17], who found the dressing rate from the broilers with a high bone ratio to be lower despite the same live weight, the dressing rate was also found to be lower in the 28-day group of this study, which had a relatively shorter period to form muscle proteins given the aforementioned broiler developmental characteristics. The weight of the breast, thigh, and wing meats significantly increased with slaughter age extension $(p<0.05)$.

Table 1. Live weight, carcass weight, and carcass rate of broiler with different slaughter age

\begin{tabular}{lrrrrr}
\hline \multirow{2}{*}{ Traits } & \multicolumn{5}{c}{ Slaughter age (d) } \\
\cline { 2 - 5 } & \multicolumn{2}{c}{$\mathbf{2 8}$} & $\mathbf{3 0}$ & $\mathbf{3 2}$ & $\mathbf{3 4}$ \\
\hline Live weight $(\mathrm{kg})$ & $1,345.50^{\mathrm{d}}$ & $1,483.00^{\mathrm{c}}$ & $1,700.50^{\mathrm{b}}$ & $1,934.00^{\mathrm{a}}$ & 31.46 \\
Carcass weight $(\mathrm{kg})$ & $995.00^{\mathrm{d}}$ & $1,128.00^{\mathrm{c}}$ & $1,279.50^{\mathrm{b}}$ & $1,454.50^{\mathrm{a}}$ & 24.67 \\
Carcass rate $(\%)$ & $71.77^{\mathrm{b}}$ & $74.31^{\mathrm{a}}$ & $74.45^{\mathrm{a}}$ & $74.32^{\mathrm{a}}$ & 0.21 \\
\hline
\end{tabular}

These experiments were conducted by randomly selecting 20 individuals broiler for each slaughter age.

All values are mean and pooled SEM.

${ }^{a-d}$ Means in the same row with different letters are significantly different $(p<0.05)$. 
Table 2. Portion meat weight of broiler with different slaughter age

\begin{tabular}{lccccc}
\hline \multirow{2}{*}{ Traits } & \multicolumn{4}{c}{ Slaughter age (d) } & Pooled SEM \\
\cline { 2 - 5 } & $\mathbf{2 8}$ & $\mathbf{3 0}$ & $\mathbf{3 2}$ & $\mathbf{3 4}$ & \\
\hline Dressing rate (\%) & $42.74^{\mathrm{b}}$ & $45.88^{\mathrm{a}}$ & $45.75^{\mathrm{a}}$ & $45.29^{\mathrm{a}}$ & 0.20 \\
Breast weight (g) & $196.48^{\mathrm{d}}$ & $230.69^{\mathrm{c}}$ & $268.36^{\mathrm{b}}$ & $303.07^{\mathrm{a}}$ & 6.60 \\
Thigh weight (g) & $259.88^{\mathrm{d}}$ & $288.19^{\mathrm{c}}$ & $321.68^{\mathrm{b}}$ & $370.17^{\mathrm{a}}$ & 6.10 \\
Tenderloin weight (g) & $30.40^{\mathrm{c}}$ & $35.45^{\mathrm{b}}$ & $44.07^{\mathrm{a}}$ & $47.08^{\mathrm{a}}$ & 0.95 \\
Wing weight (g) & $104.68^{\mathrm{d}}$ & $122.80^{\mathrm{c}}$ & $133.47^{\mathrm{b}}$ & $149.71^{\mathrm{a}}$ & 2.44 \\
\hline
\end{tabular}

These experiments were conducted by randomly selecting 20 individuals broiler for each slaughter age.

All values are mean and pooled SEM.

${ }^{a-d}$ Means in the same row with different letters are significantly different $(p<0.05)$.

The tenderloin weight showed a similar tendency, although we could not observe any significant difference between 32 and 34 days of slaughter age. According to the results of a 1986 survey, the breast and thigh meat from a carcass slaughtered at 42 days weighed $195 \mathrm{~g}$ and $235 \mathrm{~g}$, respectively [18], which are different from the currently reported weight at 34 days by approximately $63 \%-64 \%$. These results indicate that the utility value has improved with increasing meat weight that could be used as retail cuts. In Korea, most of the consumers generally avoid consumption of small broiler carcasses because there are a few amounts of edible meat [19]. In this respect, in the case of the dressing rate, since the 28 days of slaughter age showed a significantly lower value compared to other slaughter age, it is thought that the demand of consumers will not be high except in special cases.

\section{Proximate composition}

The slaughter age-based breast and thigh meat compositions are listed in Table 3. The moisture and fat contents of the breast meat did not vary significantly with the slaughter age, but the protein and ash contents increased with the slaughter age extension. Similar to the breast meat, the thigh meat moisture and fat contents did not show significant differences. The protein content was significantly lower at day 28 of slaughter age $(p<0.05)$, while no significant differences were observed between days 30 and 34. The ash content was significantly lower on days 28 and $30(p<0.05)$, whereas

Table 3. Proximate composition of broiler breast and thigh with different slaughter age

\begin{tabular}{|c|c|c|c|c|c|}
\hline \multirow{2}{*}{ Traits (\%) } & \multicolumn{4}{|c|}{ Slaughter age (d) } & \multirow{2}{*}{ Pooled SEM } \\
\hline & 28 & 30 & 32 & 34 & \\
\hline \multicolumn{6}{|l|}{ Breast } \\
\hline Moisture & 75.29 & 77.68 & 75.66 & 76.93 & 0.39 \\
\hline Protein & $23.02^{\mathrm{a}}$ & $23.58^{\mathrm{ab}}$ & $23.02^{a b}$ & $23.83^{b}$ & 0.10 \\
\hline Fat & 0.13 & 0.17 & 0.19 & 0.16 & 0.02 \\
\hline Ash & $0.99^{c}$ & $1.00^{c}$ & $1.09^{b}$ & $1.17^{\mathrm{a}}$ & 0.02 \\
\hline \multicolumn{6}{|l|}{ Thigh } \\
\hline Moisture & 76.97 & 78.46 & 76.96 & 77.24 & 0.36 \\
\hline Protein & $20.04^{\mathrm{b}}$ & $20.52^{\mathrm{a}}$ & $20.91^{\mathrm{a}}$ & $20.55^{\mathrm{a}}$ & 0.09 \\
\hline Fat & 1.48 & 1.29 & 1.11 & 1.21 & 0.07 \\
\hline Ash & $0.89^{b}$ & $0.96^{\mathrm{b}}$ & $1.07^{\mathrm{a}}$ & $1.05^{\mathrm{a}}$ & 0.02 \\
\hline
\end{tabular}

These experiments were assessed after a minimum of three repeated trials. 
there was no significant difference between days 32 and 34 . The reason for an increase in the protein content with the extended slaughter age, as shown in this study, is related to the fact that the amount of proteins generally increases as more muscles are formed during the maturation of the animals [20]. While the growth of the broilers is largely affected by breeding management during the first 4 weeks after hatching [21,22], with the growth continuing at a fast rate until sexual maturity is reached [23], chickens typically get slaughtered once they have reached 1.4-1.5 $\mathrm{kg}$ at approximately 30 days of age due to the nature of the Korean broiler market. Therefore, the protein content can vary between individual broilers of different slaughter ages since muscles are still developing quickly at the slaughter ages of 28-34 days used in this study. The difference in ash content, according to the slaughter age, is related to the change of connective tissue with age. The connective tissue structure becomes denser and firmer, increasing the extracellular fiber content, such as collagen, elastin, and reticulin, resulting in a higher composition of components other than moisture and fat. The reason for the increasing the extracellular fiber is that connective tissue, which corresponds to collagen, elastin, and reticulin, becomes fiber in the post-mortem aging process, and this connective tissue becomes denser with age, and the fiber content increases accordingly [24]. Therefore, the ash contents increased with the extending slaughter age.

\section{$\mathrm{pH}$ and color}

The $\mathrm{pH}$ level and CIE color of breast and thigh meats by slaughter age are presented in Table 4. The $\mathrm{pH}$ for the breast meat was significantly higher in the highest slaughter age group of 34 days compared to the other slaughter age groups $(p<0.05)$, and it also appeared to increase with lengthening the slaughter age for the thigh meat. A previous study reported an increasing $\mathrm{pH}$ level with increasing slaughter age for broilers from 30 to 50 days [25], similar to other poultry meat, which was consistent with this study. Changes in meat $\mathrm{pH}$ of slaughter age are concomitant with changes in lactate and glycolytic potential [26]. The slaughter age did not significantly affect the lightness and yellowness of the breast meat, but the redness increased. For the thigh meat, the lightness increased while the redness and yellowness did not vary significantly between the groups. This increased redness in the breast meat was the result of the higher maturity of broilers with increasing slaughter days of age and increasing content of myoglobin, which is a pigment-protein in the meat [27]. The decreased lightness in the thigh meat was consistent with the result from

Table 4. $\mathrm{pH}$ and $\mathrm{CIE}$ color of broiler breast and thigh with different slaughter age

\begin{tabular}{|c|c|c|c|c|c|}
\hline \multirow{2}{*}{ Traits } & \multicolumn{4}{|c|}{ Slaughter age (d) } & \multirow{2}{*}{ Pooled SEM } \\
\hline & 28 & 30 & 32 & 34 & \\
\hline \multicolumn{6}{|l|}{ Breast } \\
\hline $\mathrm{pH}$ & $5.84^{\mathrm{b}}$ & $5.84^{\mathrm{b}}$ & $5.83^{b}$ & $5.86^{a}$ & 0.01 \\
\hline CIE L* & 54.23 & 54.86 & 55.30 & 54.77 & 0.19 \\
\hline $\mathrm{CIE} \mathrm{a}^{*}$ & $3.40^{\mathrm{b}}$ & $3.60^{\mathrm{ab}}$ & $3.60^{\mathrm{ab}}$ & $4.10^{\mathrm{a}}$ & 0.10 \\
\hline $\mathrm{CIE} b^{*}$ & 8.10 & 8.10 & 8.70 & 8.13 & 0.20 \\
\hline \multicolumn{6}{|l|}{ Thigh } \\
\hline $\mathrm{pH}$ & $6.06^{c}$ & $6.14^{\mathrm{b}}$ & $6.28^{\mathrm{a}}$ & $6.34^{\mathrm{a}}$ & 0.03 \\
\hline CIE L* & $54.60^{\mathrm{a}}$ & $52.78^{\mathrm{b}}$ & $52.10^{\mathrm{bc}}$ & $51.10^{c}$ & 0.41 \\
\hline $\mathrm{CIE} \mathrm{a}^{*}$ & 4.10 & 4.27 & 5.03 & 4.97 & 0.29 \\
\hline $\mathrm{CIE} b^{*}$ & 7.45 & 7.30 & 7.11 & 6.81 & 0.16 \\
\hline
\end{tabular}

These experiments were assessed after a minimum of three repeated trials.

All values are mean and pooled (SEM).

${ }^{a-c}$ Means in the same row with different letters are significantly different $(p<0.05)$ 
Kumar and Rani [28], who similarly demonstrated differences in $\mathrm{pH}$ between the sample groups, and is attributed to the characteristic of broiler meat with a high $\mathrm{pH}$ level that tends to be low in lightness and high in redness [29]. The WHC is highly correlated with $\mathrm{pH}$ and is related to the pale soft exudative (PSE) meat. Meat with a high $\mathrm{pH}$ tends to have a higher WHC, which gives the meat more of a normal redness color as opposed to the pale color of the PSE meat [30]. When consumers purchase chicken meat, which is a type of white meat, they generally prefer to see a light red color as the normal color of chicken meat [31,32]. Also, while thigh meat is consumed with the skin, only the skinless lean meat is processed and consumed in the case of breast meat. Therefore, to maintain the meat color at the level appropriate for consumer preferences, it was determined that the slaughter age between 32 and 34 days was suitable based on the insignificant differences observed in the breast meat redness and thigh meat lightness between 32 and 34 days of slaughter age.

\section{Water holding capacity}

The WHC by slaughter age is shown in Fig. 1. Both the breast and thigh meats showed relatively low values in the 28-day group compared to the other groups $(p<0.05)$, and the 30- and 32-day groups showed a relatively higher WHC $(p<0.05)$. This study indicated a relationship between the $\mathrm{pH}$ and WHC that was slightly different from the commonly known trend; in general, meat with a high $\mathrm{pH}$ is known to have high WHC [33]. Therefore, it is thought that the WHC increased until the age of 32 days. However, the $\mathrm{WHC}$ at 34 days, despite the highest $\mathrm{pH}$, was lower than it was at 30 and 32 days. This was believed to be the effect of another factor that determines the WHC. Since the characteristics were analyzed by slaughter age in this study, the varying maturity seems to have resulted in the differences in the structure and composition of meat proteins. The quantity, spatial distribution, and composition of the connective tissues that form muscles are different depending on the age of animals, as the structure becomes denser during the process of maturation [34]. As the structure of meat proteins becomes denser, the space that retains moisture is reduced, and the WHC decreases [33]. The WHC is one of the crucial factors in the functional properties and process suitability of meat products since a higher WHC can minimize the loss of moisture during the cooking process and improve the tenderness and juiciness of the meat $[35,36]$. Thus, raw ingredient meat with superior WHC and process suitability should be used in utilizing retail cuts, and based on this study, the appropriate slaughter age from the WHC perspective was determined to be 30 and 32 days.

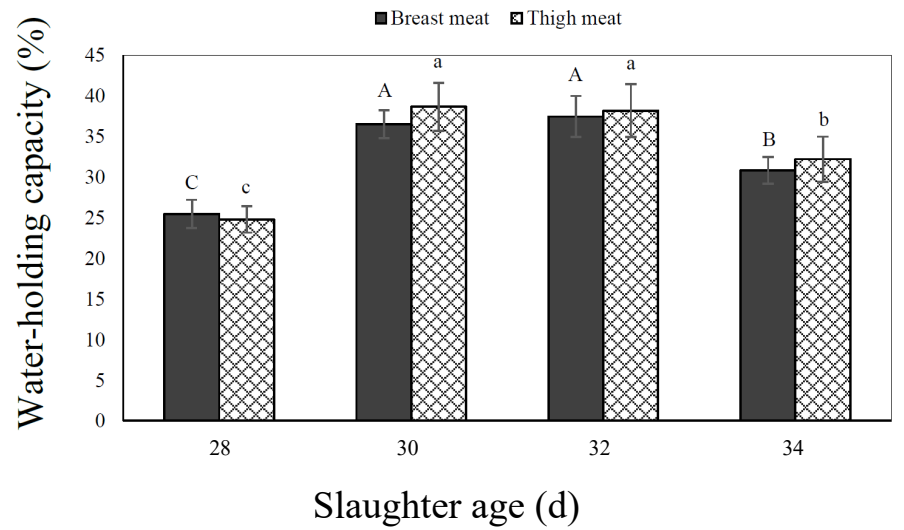

Fig. 1. Water holding capacity of broiler breast and thigh with different slaughter age. This experiment was assessed after a minimum of three repeated trials. ${ }^{A-C, a-c}$ Means in the same bar with different letters are significantly different $(p<0.05)$. 


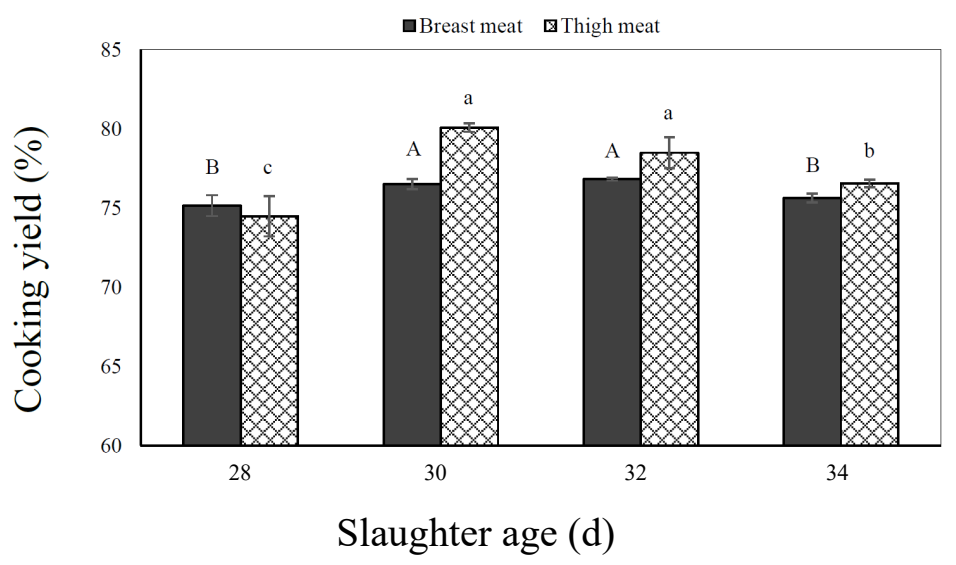

Fig. 2. Cooking yield of broiler breast and thigh with different slaughter days. This experiment were assessed after a minimum of three repeated trials. ${ }^{A, B, a-c}$ Means in the same bar with different letters are significantly different $(p<0.05)$.

\section{Cooking yield}

Fig. 2 shows the cooking yield of breast and thigh meats for different slaughter ages. The cooking yield of breast meat was significantly higher at 30 and 32 days than 28 and 34 days $(p<0.05)$, respectively. The cooking yield of thigh meat was significantly lower at 28 days compared to the other groups $(p<0.05)$, while it was significantly higher at 30 and 32 days compared to 34 days $(p<0.05)$. These differences in the cooking yield with varying slaughter age are related to WHC since high-WHC meat tends to have less moisture loss during the heating process and results in a higher cooking yield [33]. Therefore, the 30- and 32-day groups with the highest WHC showed high cooking yields. A comparable study reported that a high-WHC group in broilers showed a high cooking yield or low cooking shrinkage [37], and, a high-WHC group in processed poultry products also showed a low cooking shrinkage [38,39]. Additionally, meat high in cooking yield tends to be lower in moisture and fat contents, providing a positive effect on tenderness, taste, and flavors [40]. Therefore, the 30- and 32-day breast and thigh meat with high cooking yields were determined to be more useful as retail cuts from an economic perspective.

\section{Shear force}

The shear forces of breast and thigh meats with different slaughter ages are shown in Fig. 3. The shear force of breast and thigh meat was significantly lower at 28 days compared to the other groups $(p<0.05)$, while no significant differences were observed between 30 and 34 days. The difference in shear force according to age was because the size of sarcoplasm increases with the growth of broilers. In general, as maturity increases, the size of sarcoplasm increases, and the meat texture becomes harder [24]. Accordingly, in the case of the 28-day slaughter age, the lowest maturity had a soft texture, and the shear force was also lower than that of other slaughter days. A high portion of the breast and thigh meats of broilers is consumed in the original form as wholemuscle type products [41]. Therefore, a certain level of shear force should be attained to increase the functional characteristics of the meat to be used as a raw ingredient for whole-muscle type poultry products [12]. Additionally, meat proteins should be strong to prevent changes in appearance since the meat undergoes massaging processes, such as tumbling during the brining stage of processed meat products [42]. A suitable level of firmness should also be maintained if the meat is going to be used as a ground meat product to prevent the mixture from separating after going through the processes of grinding and mixing with other ingredients [43]. Therefore, considering these physical 


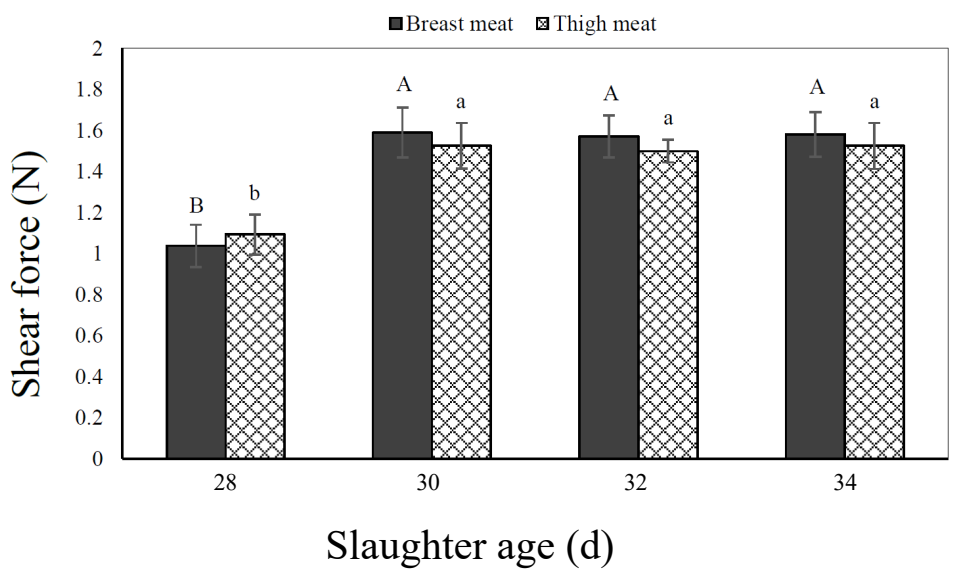

Fig. 3. Shear force of broiler breast and thigh with different slaughter days. This experiment was assessed after a minimum of three repeated trials. ${ }^{A, B, a, b}$ Means in the same bar with different letters are significantly different $(p<0.05)$. N, newton.

characteristics required for retail-cuts, the use of broilers with slaughter ages higher than 28 is believed to be appropriate.

\section{CONCLUSION}

The present study determined the broiler carcass and meat quality depending on the slaughter age (28, 30, 32, and 34 days). The live-, carcass-, and retail cut weight increased with increasing slaughter age, and the weights increased considerably compared to the past. Thus, the production index of the Korean-produced broilers has improved significantly. As an index to determine the utility of retail cuts (breast and thigh meat), $\mathrm{pH}$ and shear force increased as the slaughter age increased, and the WHC and cooking yield of 30 and 32 days were higher than 28 and 34 days, respectively. Therefore, this study recommends optimizing retail cuts quality at 30 and 32 days based on general slaughter days.

\section{REFERENCES}

1. Kim GW, Kim JH, Kim HY, Kim BK, Park HB, Choe J, et al. Analysis of marketing performances according to raising environment in broilers. Korean J Poultry Sci. 2019;46:25-30. https://doi.org/10.5536/KJPS.2019.46.1.25

2. KREI. Livestock trend observation. Broiler; 2020 Jan. [Internet]. Korea Rural Economic Institute. 2020. [cited 2020 Jan 30]. https://aglook.krei.re.kr/jsp/pc/front/observe/monthlyReport. jsp?ovr_item_code=OVR0000000014\&xrt_ovr_item_code=OVR0000000020

3. Nasr J, Kheiri F. Increasing amino acids density improves broiler live weight. Int J Poult Sci. 2011;10:523-6. https://doi.org/10.3923/ijps.2011.523.526

4. Chae HS, Choi HC, Na JC, Jang AR, Kim MJ, Bang HT, et al. Effects of raising periods on physico-chemical meat properties of chicken. Korean J Poultry Sci. 2011;38:285-91. https:// doi.org/10.5536/KJPS.2011.38.4.285

5. Barbut S. Convenience breaded poultry meat products - New developments. Trends Food Sci Tech. 2012;26:14-20. https://doi.org/10.1016/j.tifs.2011.12.007

6. Charlton KE, Probst Y, Tapsell LC, Blackall PJ. Food, health and nutrition: where does chicken fit? J Home Econ Inst Aust. 2008;15:5-17. 
7. KMTA. The current state of import for chicken portion meat [Internet]. Korea Meat Trade Association. 2020 [cited 2020 Jun 2]. http://www.kmta.or.kr/kr/data/stats_import_chicken_ parts.php

8. Jeong YD, Jeon BS, Ryu KS. Effect of various organic dietary ME and CCP on performance, blood composition and meat quality in meat type cross-bred chicks. Korean J Poult Sci. 2009;36:139-47. https://doi.org/10.5536/KJPS.2009.36.2.139

9. AOAC. Official methods of analysis. 15th ed. Washington DC: Association of Official Analytical Chemists; 1990.

10. Grau R, Hamm R. Eine einfache methode zur bestimmung der wasserbinding in muskel. Naturwissenschaften 1953;40:29-30. https://doi.org/10.1007/BF00595734

11. NIAS. Characteristices of chicken meat [Internet]. National Institute of Animal Science. 2017 [cited 2020 May 20]. http://www.nongsaro.go.kr/portal/ps/psb/psbk/kidoContentsFileView. ps?ep=SRafvgcz7ZIqtMkSj13MnS8eXKTG0XMk11R13qw8fcA!

12. Choi HC. Large broiler production technology and economic effect [Internet]. National Institute of Animal Science. 2015 [cited 2020 Jun 2]. http://www.nias.go.kr/front/soboarddown. do? $\mathrm{cm}$ Code=M090814151125016\&boardSeqNum=897\&fileSeqNum=946

13. Na JC, Choo HJ, Kim DW, Hwangbo J, Kim JH, Kang HG, et al. Growth performance and carcass yield of heavy female broiler at different stocking densities. Korean J Poult Sci. 2013;1:41-7. https://doi.org/10.5536/KJPS.2013.40.1.041

14. Mollah MR, Hasan A, Salam A, Ali A. Digital image analysis to estimate the live weight of broiler. Comput Electron Agr. 2010;72:48-52. https://doi.org/10.1016/j.compag.2010.02.020

15. Choe JH, Lee JC, Jo C. Relationship between the economical defects of broiler meat carcass and quality grade A with a meat grader. Korean J Food Sci Anim Resour. 2009;29:494-9. https://doi.org/10.5851/kosfa.2009.29.4.494

16. Oh BK. Poultry science. 3rd ed. Seoul: Munundang; 2018.

17. Devatkal SK, Naveena BM, Kotaiah T. Quality, composition, and consumer evaluation of meat from slow-growing broilers relative to commercial broilers. Poultry Sci. 2019;98:6177-86. https://doi.org/10.3382/ps/pez344

18. Chen TC, Omar S, Schultz D, Dilworth BC, Day EJ. Processing, parts, and deboning yields of four ages of broilers. Poultry Sci. 1986;66:1334-40. https://doi.org/10.3382/ps.0661334

19. Ahn BK, Kim JY, Kim JS, Lee BK, Lee SY, Lee WS, et al. Comparisons of the carcass characteristics of male white mini broilers, ross broilers and hy-line brown chicks under the identical rearing condition. Korean J Poult Sci. 2009;36:149-55. https://doi.org/10.5536/ KJPS.2009.36.2.149

20. Barteczkso O, Lasek O. Effect of varied protein and energy contents in mixture on meat quality of broiler chicken. Slovak J Anim Sci. 2008;41:173-8.

21. PinHeiro DF, Cruz VC, Sartori JR, Vicentini Pauline MLM. Effect of early feed restriction and enzyme supplementation on digestive enzyme activities in broilers. Poultry Sci. 2004;83:1544-50. https://doi.org/10.1093/ps/83.9.1544

22. Acar N, Sizemore FG, Leach GR, Wideman Jr RF, Owen RL, Barbato GF. Growth of broiler chickens in response to feed restriction regimens to reduce ascites. Poultry Sci. 1955;74:833-43. https://doi.org/10.3382/ps.0740833

23. Marks HL. Growth rate and feed intake of selected and nonselected broilers. Growth. 1979;43:80-90.

24. Taylor RG. Connective tissue structure, function and influence on meat quality. In: Jensen WK, Devive C, Dikeman M, editors. Encyclopedia of meat sciences. Amsterdam: Elsevier; 2004. p. 306-13.

25. Abougabal MS, Taboosha MF. Productive performance, carcass characteristics and meat quali- 
ty of broiler chickens at different marketing ages. Egypt Poult Sci. 2020;40:275-89. https://doi. org/10.21608/epsj.2020.81033

26. Dadgar S, Lee ES, Leer TLV, Crowe TG, Classen HL, Shand PJ. Effect of acute cold exposure, age, sex, and lairage on broiler breast meat quality. Poultry Sci. 2011;90:444-57. https:// doi.org/10.3382/ps.2010-00840

27. Renerre M. Factors involved in the discoloration of beef meat. Int J Food Sci Tech. 1990;25:613-30. https://doi.org/10.1111/j.1365-2621.1990.tb01123.x

28. Kumar RP, Rani MS. Chemical composition of chicken of various commercial brands available in market. J Agr Vet Sci. 2014;7:22-6. https://doi.org/10.9790/2380-07732226

29. Barbut S. Problem of pale soft exudative meat in broiler chickens. Brit Poultry Sci. 1997;38:355-8. https://doi.org/10.1080/00071669708418002

30. Sarica M, Boz MA, Yamak US, Ucar A. Effect of production system and slaughter age on some production traits of guinea fowl: meat quality and digestive traits. S Afr J Anim Sci. 2019;49:192-9. https://doi.org/10.4314/sajas.v49i1.22

31. Kennedy OB, Stewart-Knox BJ, Mitchell PC, Thurnham DI. Flesh colour dominates consumer preference for chicken. Appetite. 2005;44:181-6. https://doi.org/10.1016/j.appet.2004.11.002

32. Qiao M, Fletcher DL, Smith DP, Northcutt JK. The effect of broiler meat color on $\mathrm{pH}$, moisture, water-holding capacity, and emulsification capacity. Poult Sci. 2001;80:676-80. https://doi. org $/ 10.1093 / \mathrm{ps} / 80.5 .676$

33. Huff-Lonergan E. Water-holding capacity of fresh meat. Des Moines, IA: National Pork Producers Council; 2002. American Meat Science Association Fact Sheet: 04669.

34. Purslow PP. Intramuscular connective tissue and its role in meat quality. Meat Sci. 2005;70:435-47.https://doi.org/10.1016/j.meatsci.2004.06.028

35. Aleson-Carbonell L, Ferna'ndez-Lo'pez J, Pe'rez-Alvarez JA, Kuri V. Characteristics of beef burger as influenced by various types of lemon albedo. Innovative Food Sci Emerging Technol. 2005;6:247-55. https://doi.org/10.1016/j.ifset.2005.01.002

36. Park SY, Kim HY. Electric field induced super-cooling system for long term dry-aged beef loin. Food Sci Anim Resour. 2020;40:286-96. https://doi.org/10.5851/kosfa.2020.e14

37. Woelfel RL, Owens CM, Hirschler EM, Martinez-Dawson R, Sams AR. The characterization and incidence of pale, soft, and exudative broiler meat on a commercial processing plant. Poultry Sci. 2002;81:579-84. https://doi.org/10.1093/ps/81.4.579

38. Komolrti P, Pakdeechanuan P. Effects of marinating ingredients on physicochemical, microstructural and sensory properties of golek chicken. Int Food Res J. 2012;19:1449-55.

39. Karunaranayaka SD, Jayasena DD, Jo C. Prevalence of pale, soft, and exudative (PSE) condition in chicken meat used for commercial meat processing and its effect on roasted chicken breast.J Anim Sci Tech. 2016;58:27. https://doi.org/10.1186/s40781-016-0110-8

40. Hughes JM, Oiseth SK, Purslow PP, Warner RD. A structural approach to understanding the interactions between colour, water-holding capacity and tenderness. Meat Sci. 2014;98:520-32. https://doi.org/10.1016/j.meatsci.2014.05.022

41. Smith DP. Marination, cooking, and curing of poultry products. In: Casey MO, editor. Poultry meat processing. Boca Raton: CRC Press; 2010. p. 311-37.

42. Singh P, Yadav S, Pathera A, Sharma D. Effect of vacuum tumbling and red beetroot juice incorporation on quality characteristics of marinated chicken breast and leg meats. Nutr Food Sci. 2019;50:143-56. https://doi.org/10.1108/NFS-03-2019-0079

43. Kim SY, Choi JH, Choi YS, Kim HY, Ahn KI, Kim HW, et al. Effects of low-temperature tumbling on the quality characteristics of restructured chicken breast ham. Korean J Food Sci Anim Resour. 2012;32:268-73. https://doi.org/10.5851/kosfa.2012.32.3.268 